\title{
タッピング頻度と咬合カの変化が筋活動におよぼす影翌
}

Effects of Tapping Frequency and Biting Force on Electromyography of Masster Muscle

渡辺誠, 宗 形 芳 英, 三 浦 周太郎, 高藤 道夫, 鹿 沼 晶 夫

Makoto Watanabe, Yoshiei Munakata, Shutaro Miura, Michio Takafuji and Akio Kanuma 東北大学歯学部歯科補緅学第二講座

Second Department of Prosthetic Dentistry, Tohoku University School of Dentistry.

1.はじめに

顎口腔系の機能の診査, 診断法として, 咀嚼 筋の活動を把握することは不可欠であり, その 代表的な方法として, 従来より筋電図が多く用 いられている。しかしなからら，咀嚼運動や開閉 口運動にともなう筋電図は，その運動が随意的 であればあるほど, 筋活動にばらつきがみられ るため，定性的な分析が困難である。そこで， われわれは規則的な音信号を与え，その信号に 従ってタッピング運動をさせることで, できる だけ反射機構としてのタッピング運動を誘発さ せるととを試み，それにともなう咬筋筋電図お よび咬合力についての検討を行ってきた。

今回は, タッピングの頻度の変化に加え, タ ッピング運動により発現する咬合力を, 被験者 の視覚フィードバックにより規則的に変化させ, これらの変化が咬筋筋電図の持続時間の長さや 振幅の大きさにどのような影響をおよぼすかに ついて検討を行い, タッピング頻度および咬合 力と筋電図との対応関係について検索を行った。

\section{2. 被釦者および実験方法}

顎口垫系に異常に認められない正常咬合を有 する25歳〜35歳 (平均 27.3 歳) の男性 7 名を被 験者とした。

種々の頻度の音記号をスピーカーより発し， 被験者か，信号に合わせてタッピンク連動を るように指示した。なお実験で用いたタッピン グ頻度は， $0.5 ， 1 ， 2 ， 3 ， 5,7 \mathrm{~Hz}$ の 6 段階 とした。筋電図の導出部位としては左側咬筋中 央部から極間距離 20 m の表面電極により双極導 出とした。
一方, タッピング運動時の咬合力を测定する 目的で, 下影装着型のOcclusal Splintに匠力セ ンサーをうめこみ, 下䫑中切歯部に加わる咬合 力を導出した。さらに圧力センサーからの出力 をモニター用オシロスコープ上に表わし，タッ ピング運動時の咬合力が指示された大きさにな るように被験者が視覚的に調節できるようにし た(図 1 )。

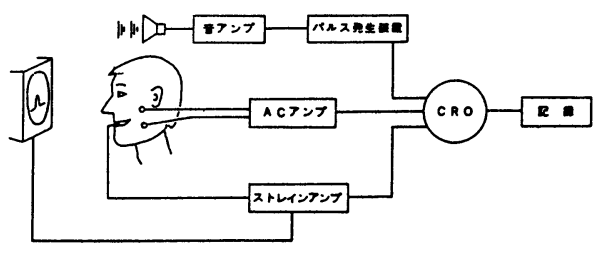

図1. ブロックダイヤグラム

実験は以下の 2 通りに分けて行なった。

まず, 実験 Aとして, タッピング頻度のみを 指示された数段階に変化させ，これにともなう 咬筋筋電図を記録し観察した。この場合タッピ ング時の咬合力について指示は与えず, 被耠者 の咬みやすい大きさにまかせた。

次に，実験 Bとして，タッピング頻度の変化 に加えタッピング運動時の咬合力をも種々に㚆 化させ，それにともなう筋電図の変化を锶察し た。

なお，実験に際しては，被検者に同一条件下 で十分な練習を行なわせた。さらに，測定回ど とに十分な休息を与え, 測定結果に, 疲労の影 整がなるへく少なくなるように配虑した。

各実験により得られた筋電図および咬合力の 
波形は，いったんデータレコーダーに保存し， 実験終了後, 再度オシロスコープ上に表わし写 真撮影した。計測は, 現像したフィルムを万能 投影機上で拡大し，次に示す各測定項目につい てキャリパスを用いて行った。

計測項目は以下の 6 種類である。

1) Silent Period ( SP) 前波形 $\left(B_{1}\right)$ の持続 時間 …... $B_{1}-D$

2) $\mathrm{B}_{1}$ の放電振幅のピーク值 $\cdots \cdots \cdot \mathrm{B}_{1}-\mathrm{A}$

3) SP の持続時間 …... SP $-\mathrm{D}$

4) $\mathrm{SP}$ 後波形 $\left(\mathrm{B}_{2}\right)$ の持続時間 $\cdots \cdots \cdot \mathrm{B}_{2}-\mathrm{D}$

5) $\mathrm{B}_{2}$ の放電振幅のピーク值 ….... $\mathrm{B}_{2}-\mathrm{A}$

6) 咬合力のピーク值 $\cdots \cdots \cdot \mathrm{BF}-\mathrm{A}$

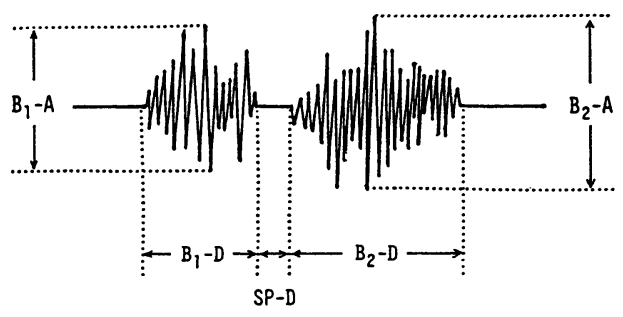

図 2. 本実験の計測項目 (筋電図)

\section{3. 実 験 結 果}

（実験 A）タッピング頻度のちがいが EMGおよ び咬合力におよぼす影響

結果は以下のとおりである(図 3 )。

(1) $\mathrm{B}_{1}$-Dはタッピング頻度の変化に対して あまり影響がみられなかった。

(2) $\mathrm{B}_{2}-\mathrm{D}$ は $0,5 \mathrm{~Hz}$ から $2 \mathrm{~Hz}$ の間では増加傾 向にあり, $2 \mathrm{~Hz}$ 以上では頻度の上昇にとすない 短縮した。

(3） SPーDはタッピング頻度の上昇にともな い短縮した。

(4) $\mathrm{B}_{1}-\mathrm{A}$ は $3 \mathrm{~Hz}$ まではタッピング頻度の上 昇にともない減少傾向を示したか， $3 \mathrm{~Hz}$ 以上で は逆に增加傾向を示した。

(5) $\mathrm{B}_{2}$ - $\mathrm{A}$ はタッピング頻度の上昇ととむに 減少した。

(6) 咬合力は, 頻度の上昇にとむない減少し た。

（実験 B）各タッピング頻度における咬合力の 変化がEMGにおよぼす影響

実験 $\mathrm{A}$ における $0.5 \mathrm{~Hz}$ での咬合力を基準とし,
その $1 / 2$ 倍に咬合力を減少させた場合について 検討を行った。

この実験により得られた測定結果の例を $\mathrm{B}_{2}$ Dについて図示した(図 4)。次に咬合力が半分 に減少するてとによって, EMGの各要素がどの くらいの割合で減少するか, 基準の咬合力での 各要素の值を $100 \%$ とし，それらの減少率につ いて検討を行った(図 5)。

図 5 の縦軸は, 減少率を示し, 横軸は, EMG の各要素を示している。図中の棒グラフは, 0.5 $5 \mathrm{~Hz}$ 各々の減少率の平均値を示している。 図から明らかなように，咬合力の減少により， 平均値では, $\mathrm{B}_{2}-\mathrm{A}, \mathrm{B}_{1}-\mathrm{A}, \mathrm{B}_{2}-\mathrm{D}, \mathrm{SP}-\mathrm{D}$, $\mathrm{B}_{1}$-Dの順に小さくなり,一方，タッピング頻 度の違いによる减少率のばらつきにおいては， $\mathrm{B}_{1}-\mathrm{D}, \mathrm{B}_{1}-\mathrm{A}, \mathrm{B}_{2}-\mathrm{A}$ に比べ $\mathrm{SP}-\mathrm{D}, \mathrm{B}_{2}-\mathrm{D}$ の 2 者が明らかな違いを示し大きくなっている。

ここで, 減少率が大きいということは, 咬合 力の変化に対して大きく影響をうけやすいとと を示し，ばらつきが大きいというととは，タッ ピング頻度の変化に対して，影響をうけやすい ことを示すことから，実験 Bの結果を次のよう にまとめることができる。

(1) $\mathrm{B}_{1}$-Dはタッピング頻度および咬合力の の変化に対して，ほとんど無関係に，ほぼ一定 の值を示す。

(2) $\mathrm{B}_{1}-\mathrm{A}, \mathrm{B}_{2}-\mathrm{A}$ の両者は, 咬合力の変化 に大きく影響をうけるが, その影響のうけ方は タッピング頻度のちがいには，ほとんど影響さ れない。

(3) $\mathrm{B}_{2}-\mathrm{D}, \mathrm{SP}-\mathrm{D}$ の両者は, ある程度, 咬合力の変化に影響をうけるが, むしろ, タッ ピング頻度の変化による影響を大きくうけやす い。

\section{4. まとめ}

正常有歯顎者におけるタッピング運動時の咬 筋筋電図は，タッピング頻度およびタッピング 時の咬合力のちがいにより定性的な変化を示す ことが明らかになった。このことは，䫟口腔機 能に問題のある患者での筋電図学的診查をおこ なう際の有用な指標になるととを示唆してい る。 

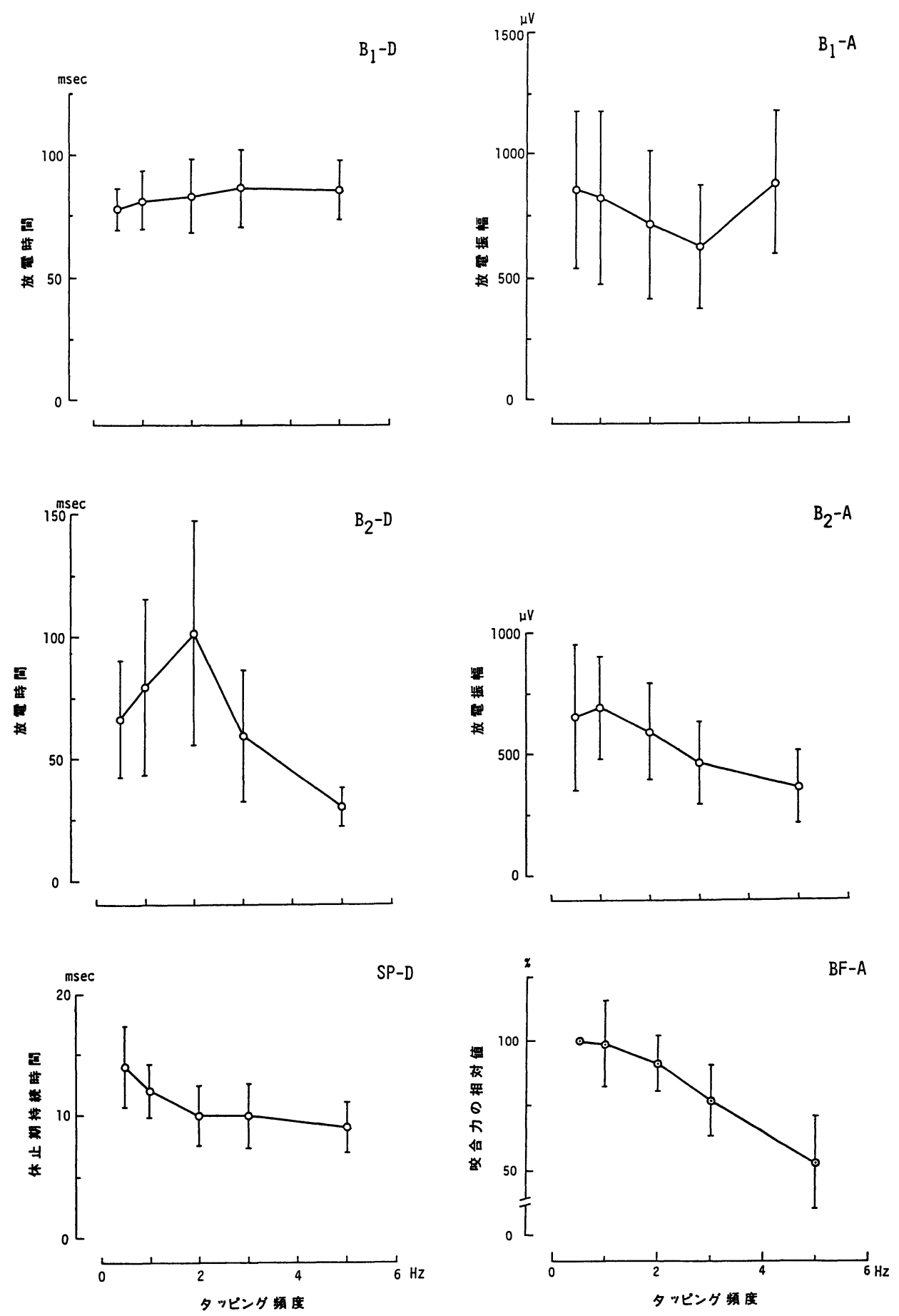

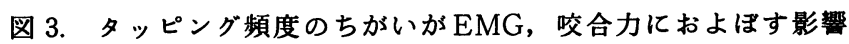




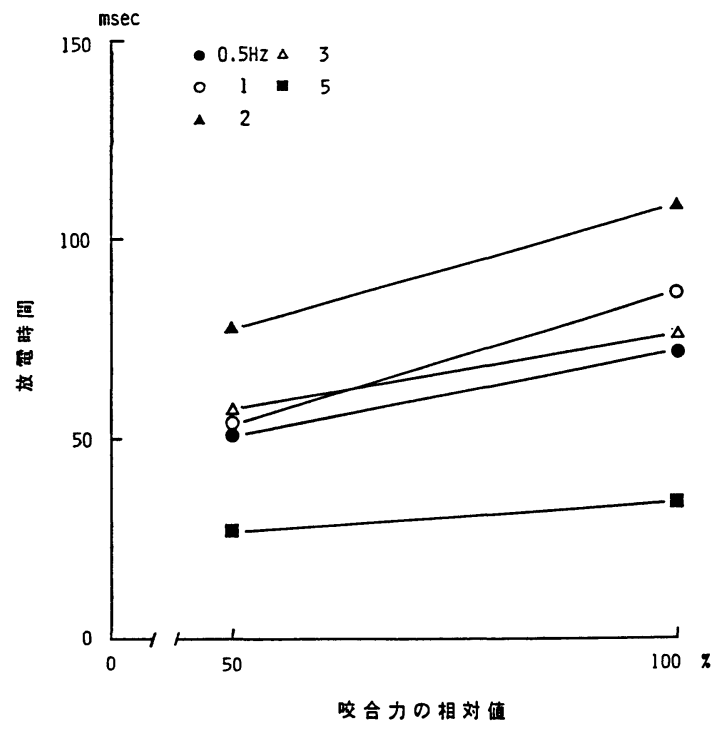

図 4. 咬合力の変化による $\mathrm{EMG}\left(\mathrm{B}_{2}-\mathrm{D}\right)$ の変化

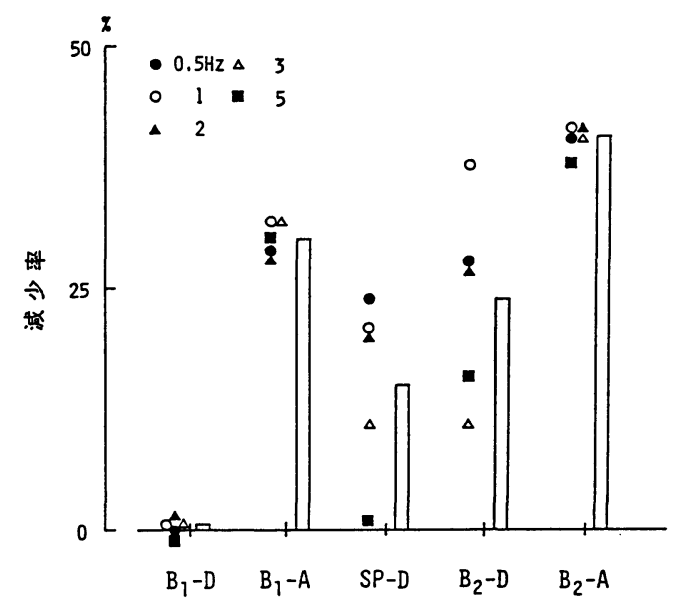

図 5. 咬合力の減少によるEMGの減少率

\section{参考 文 献}

1）三浦周太郎, 宗形芳英, 高藤道夫, 渡辺誠, 鹿沼晶夫：タッピング頻度による咬筋活動の 変化 (講演抄録). 補緅誌, $28: 955,1984$. 